\title{
Rapport Between Leverage and Profitability: A Study of TVS Motor Company
}

\author{
Gautam Sen ${ }^{1}$, Ravi Ranjan ${ }^{2, *}$ \\ ${ }^{1}$ Department of Commerce,Assam Don Bosco University,Guwahati, India \\ ${ }^{2}$ Amity College of Commerce, Amity University, Gurgaon, India \\ E mail Address: \\ gautam.sen@dbuniversity.ac.in (G. Sen), raviranjanshrivastava123@gmail.com (R. Ranjan) \\ ${ }^{*}$ Corresponding author
}

\section{To cite this article:}

Gautam Sen, Ravi Ranjan. Rapport Between Leverage and Profitability: A Study of TVS Motor Company. Journal of Finance and Accounting. Vol. 6, No. 2, 2018, pp. 49-55. doi: 10.11648/j.jfa.20180602.11

Received: March 12, 2018; Accepted: April 9, 2018; Published: May 11, 2018

\begin{abstract}
Leverage analysis can be defined as a process of identifying the financial strength and weakness of a firm from the available data and financial statements. A firm needs funds so run and manage its activities. The funds are needed to set up an enterprise and then to implement expansion, diversification and other plans. A decision has to be made regarding the composition of funds. In this paper an attempt has been made to analyze the impact of leverage on the profitability and performance of the company. For the purpose of the study TVS motor Co. has been selected and for analysis purpose the basic statistical tools like Mean, SD, CV, CAGR, ANOVA(one way) have been used and in order to measure the impact the OLS simple Linear regression model has been used, the study covers a period of ten years from 2006 to 2016 . Results suggested that the operating, financial and combined leverage of the company does not play any major role in making investment decisions of the company. And it was also found that the financial, operating and combined leverage of the company has no significant impact on ROA (Return on Assets) and Risk Adjusted (SHROA) of the company.
\end{abstract}

Keywords: Roa, Shroa, Liquidity, Leverage \& Risk

\section{Introduction}

Finance is the life blood of every economic activity. It is the study of funds and management. Its general areas are business finance, personal finance, and public finance. It also deals with the concept of time, money, risk, and the interrelation between the given factors. Leverage analysis is the methodical classification of the data given in the financial statement. It is the process of identifying the financial strength and weakness of a firm from the available accounting data and financial statements.A firm needs funds so run and manage its activities. The funds are first needed to set up an enterprise and then to implement expansion, diversification and other plans. A decision has to be made regarding the composition of funds. The funds may be raised through two sources-owners called owners equity, and outsiders, called creditor's equity. When a firm issues capital these are owner's funds, when it raises, funds by raising longterm and short-term loans it is called creditors or outsiders equity. Various means used to raise funds represent the financial structure of a firm. So the financial structure is represented by the left side of the balance sheet i.e. liabilities side. The use of long-term fixed interest bearing debt and preference share capital along with equity share capital is called financial leverage. The long-term fixed interest bearing debt is employed by a firm to earn more from the use of these resources than their cost so as to increase the return on owner's equity. It is true that the capital structure cannot affect the total earnings of a firm but it can affect the share of earnings for equity shareholders. The fixed cost funds are employed in such a way that the earnings available for common stockholders (equity shareholders) are increased. A fixed rate of interest is paid on such long-term debts (debentures, etc.). The interest is a liability and must be paid irrespective of revenue earnings. The preference share capital also bears a fixed rate of dividend. But, the dividend is paid only when the company has surplus profits. The equity shareholders are entitled to residual income after paying interest and preference dividend. The aim of financial leverage is to increase the revenue available for equity shareholders using the fixed cost funds. If the revenue earned by employing fixed cost funds is 
more than their cost (interest and/or preference dividend) then it will be to the benefit of equity shareholders to use such a capital structure. A firm is known to have a favorable leverage if its earnings are more than what debt would cost. On the contrary, if it does not earn as much as the debt costs then it will be as an unfavorable leverage. On the other words, favorable or positive leverage occurs when the firm earns more on the assets purchased with the funds, than the fixed cost of their use. Unfavorable or negative leverage occurs when the firm does not earn as much as the funds cost. In theory, capital structure can affect the value of a company by affecting either its expected earnings or the cost of capital, or both. While it is true that financing mix cannot affect the total operating earnings of a firm, as they are determined by the investment decisions, it can affect the share of earnings belonging to the ordinary shareholders. The capital structure decision can influence the value of the firm through the earnings available to the shareholders. But the leverage can largely influence the value of the firm through the cost of capital.

\subsection{Conceptual Framework}

\subsubsection{Leverage}

In general terms leverage refers to lifting of heavy objects with less effort but in financial management the term 'leverage' refers to the use of fixed cost funds to increase the earnings of the shareholders. Leverage refers to percentage change in dependent factor due to percentage change in independent factor.It is also known as analysis of risk.Leverage means to have fixed cost for a business. There are two types of fixed cost i.e., fixed operating cost and fixed financial cost.Leverage is a business term that refers to borrowing.If a business is "levered" it means that the business has borrowed money to finance the purchase of assets. Purpose of leverage is to raise profits; a high degree of leverage gives a big push upward to profits. If it properly used, it serves it purpose well and its effects are favorable. In leverage two factors are considered i.e., Risk and Return.

\subsubsection{Risk}

While leverage magnifies profits when the returns from the asset more than offset the costs of borrowing, leverage may also magnify losses. A corporation that borrows too much money might face bankruptcy or default during a business downturn, while a less-leveraged corporation might survive. Risk means occurrence of loss. It means you have a possibility of losing some or even all of your investment. Through leverage we can easily measure that there is a high risk or low risk. There are two types of risk i.e., Operating and Financial risk.Operating risk arises due to use of fixed operating cost i.e., rent of factory, depreciation on fixed assets etc.Financial risk arises due to use of fixed financial cost i.e., interest on loan, interest on debentures etc. Composite/Combined risk arises due to use of fixed operating cost fixed financial cost.

\subsubsection{Return}

In finance, return is a profit on an investment. It comprises any change in value and interest or dividend or other such cash flows which the investor receives from the investment.

\subsubsection{Types of Leverage}

There are mainly two types of leverage i.e., Operating leverage and Financial leverage but there is one more leverage which is known as Combined leverage, it is not a type of leverage but it is a combination of operating and financial leverage.

\section{(i) Operating Leverage}

The operating leverage may be defined as the firm's ability to use fixed operating costs to magnify the effects of changes in sales on its EBIT. The business entities employ assets with fixed cost in the hope that volume will produce revenues more than sufficient to cover all fixed and variable costs.

\section{(ii) Financial Leverage}

Financial leverage is the use of fixed financing costs by the firm. The use of fixed interest or dividend bearing securities such as debt and preference capital along with the owner's equity in the total capital structure of the company is described as financial leverage. The financial leverage employed by a company is intended to earn more return on the fixed charge funds than their costs.

\section{(iii) Combined Leverage}

Degree of Combined leverage summarizes the combined effect of degree of Operating leverage and degree of financial leverage on earning per share. It indicates the effect that changes in sales will have on EPS. Since both these leverages are closely concerned with ascertaining the ability to cover fixed charges (fixed operating cost in the case of OL and fixed financial costs in the case of FL), if they are combined, the result is total leverage and the risk associated with $\mathrm{CL}$ is known as total risk.

\subsection{Company Profile (TVS Motor Company)}

TVS Motor is the third largest two-wheeler manufacturer in India, with revenue of 11,244 Cr INR (2015-16). The company has annual production capacity of 3.2 million 2 wheelers \& 1.2 Lakh 3 wheelers.The TVS Group was established back in 1911, when the founder of the company, Shri T V SundaramIyengar created an enduring business, led by a family of like-minded workers and managers united by a set of high, yet shared principles. Driven by this inspiration, the TVS group has today emerged as India's leading player in the automobile and automotive components industries.TVS Group spans across industries like Automobile, Aviation, Education, Electronics, Energy, Finance, Housing, Insurance, Investment, Logistics, Service and Textiles. The group has over 90 Companies under the umbrella.TVS Motor Company Ltd (TVS Motor), member of the TVS group (Revenue around INR. 40,000 $\mathrm{Cr}$ in 2015-16), is the largest company of the group in terms of size and turnover.TVS has been at the forefront in bringing a revolution in the way personal commutation was happening, way back in the 1980s. Beginning with launching a simple, easy-to-use moped for 
the middle class in India in the 1980s to launching seven new bikes in a single day (first time in the history of the automotive industry in the world), TVS has often taken the unbeaten path to innovation.

\section{Review of Literature}

A study has been conducted by [2] where they studied whether the trade liberalization affects profitability and financial leverage, using Canadian data from the period following implementation of the Canada-U.S. Free Trade Agreement. They concluded that falling domestic tariffs are linked with declining profits and increasingleverage for import-competing firms, while falling foreign tariffs are linked with increasingprofits and decreasing leverage for firms in export-oriented industries.

Another similar study had been conducted by [1] and his study he has included sample of 121 listed companies on the Jordanian Stock Exchange extended from the period 2007 to 2010. In this sample only the industrial and service sectors have been taken for the study purpose. The outcomes show that for both industrial and services sectors; there were no statistical significant relationship. When the two sectors were separated, the outcomes for the industrial sector revealed that liquidity and tangibly have significant relationship with leverage, whereas the outcomes for the services sector revealed that the growth rate, liquidity, and tangibility have significant relationship with leverage.

Leverage plays an important role in improving the overall efficiency of the firm or organization a study had been carried out by [5] where efforts had been made to analyze the effects of financial leverage on efficiency of firms in Pakistan. 154 textile firms in Pakistan over the period 20062011 have been taken for the study purpose. The outcomes indicate that the leverage is negatively associated with the efficiency of firms. Financial leverage is negatively associated with return of assets and equity, which shows that firms borrow less, while market-to-book ratio shows positive profitable association with firms. Consequently firms tend to borrow more and pay their contractual payments in time. Similar study had been carried out by [3] this study was based on the effect of financial leverage on profitability and also the presence of smoothing in listed companies of Tehran Stock Exchangeduring 2006-2010 period. For the study, 60 companies listed on the Tehran Stock Exchange were selected. Following statistical techniques such as simple linear regression and Pearson's correlation test and finally used in ECKEL model for identifying smoothing firms from non-smoothing. The outcomes of this research paper confirmed the presence of smoothing and relationships between financial leverage and profitability in listed companies of Stock Exchange. The keyoutcome of the study indicates that despite of significant relationship between some variety of research hypotheses in smoothing and nonsmoothing firms, there are significant differences between financial leverage and profitability between these two groups of firms. A parallel type of study had been carried out by [9] and it was based on the effect of financialleverage on selected indicators of corporate performance in Nigeria.The result revealed that Leverage shocks exertsubstantially on corporate performance in Nigeria.Leverage therefore significantly affects corporate performance in Nigeria. On the contrary. On the contrary a study had been conducted by [7] and their paper studies the relationship between Financial Leverage and Return of Investment, Operating Leverage and Return on Investment, and Combined Leverage and Return on Investment, for Dr Reddy's Laboratories, the pharmaceutical firm during 2010 to 2014 period.The objective of this paper is also to know the decisions made by Dr Reddy's Laboratories with regards to its asset utilization and Leverage management. This research paper thus analyzes the impact of these decisions on the Shareholder's earnings and the Earnings before Interest and Taxes.Dr Reddy's Laboratories had the highest sales turnover for the financial year 2013-14.

\section{Research Methodology}

The major aim of the study is to empirically investigate the brunt of the determinants of leverage on the financial, operating and combined leverage of the company and further to analyze the impact of leverage on the overall profitability of the company.

\subsection{Objectives}

1. To examine the impact of the leverage determinants of the company which influence in the selection of the source of financing investments.

2. To examine the impact of leverage on the profitability of the company.

In order to seek the above objectives followings hypotheses have been formulated:

$\mathrm{H}_{01}$ : The leverage determinants have no significant impact on the financial, operating and combined leverage of the company.

$\mathrm{H}_{02}$ : The financial, operating and combined leverage of the company has no significant impact on ROA (Return on Assets) of the company.

$\mathrm{H}_{03}$ : The financial, operating and combined leverage of the company has no significant impact on SHROA (Risk Adjusted Return on Assets) of the company.

\subsection{Data Source}

The secondary has mainly been used in the study and it has been collected from the annual reports of the company (source: https://www.tvsmotor.com/).

\subsection{Study Period}

Study period covers a period of 10 years starting from the period of $1^{\text {st }}$ April, 2006 to $31^{\text {st }}$ March, 2016.

\subsection{Leverage Determinants}

To investigate the relationship between leverage 
determinants and financial performance of the company following variables has been used in the study:

(1) Growth (in terms of total assets):GR (intermsofTotalAssets) $=\frac{\left(P_{1}-P_{0}\right)}{P_{1}} \times 100$

Here, $\mathrm{P}_{0}$ represents previous year and $\mathrm{P}_{1}$ represents current year:

(2) $\operatorname{ROA}($ Return on Assets): ROA (Return on Assets) $=$ Profit (After Tax)

Total Assets

(3) SHROA(Risk Adjusted Return on

Assets:SHROA (Risk adjusted ROA) $=\frac{\text { ROA }}{\sigma \text { ROA }}$

Here, $\sigma$ ROAis the standard deviation of ROA

(4) Liquidity: CA (Current Asset) $=\frac{\text { Current Asset }}{\text { Current Liability }}$

(5) Tangibility: TL (Tangibility) $=\frac{\text { Fixed Assets }}{\text { Total Assets }}$

(6) Size(SZ): Size is measured by the natural logarithm of total assets of the company.

(7) Financial leverage (FL): FL (Financial leverage ) = $\frac{\text { EBIT }}{\text { PBT }}$

OR

$$
\text { FL }(\text { Financial leverage })=\frac{\% \text { Change in EPS }}{\% \text { Change in EBIT }}
$$

Here, PBT $($ Profit before Tax $)=$ EBIT - Financial Charge, EBIT $=$ Earnings before Interest and Taxes $=$ Total contribution - Fixed costs and EPS (Earnings per share) = Earnings after Taxes (EAT)/ No. of shares.

(8) Operating Leverage (OL): OL (operatingLeverage) = Contribution

OR

$$
\text { OL (operatingLeverage) }=\frac{\% \text { Change in EBIT }}{\% \text { Change in Sales }}
$$

Here, Operating Income (i.e., EBIT) =Total contributionFixed costs and Contribution $=$ Sales - Variable costs

(9) Combined Leverage $(\mathrm{CL})$ : CL (Combined Leverage) $=$ Operating Leverge $\mathrm{X}$

\section{Financil Leverage}

OR

$$
\text { CL }(\text { Combined Leverage })=\frac{\% \text { Change in EPS }}{\% \text { Change in Sales }}
$$

Here, EPS = Earnings Per share

\subsection{Statistical Tools and Techniques}

Statistical tools like CAGR (Compound Annual Growth Rate)ANOVA(one way, Coefficient of Correlation, Coefficient of Variation (C.V.), Standard Deviation, Meanetc being used for the purpose of the study.

\subsection{Measure of Leverage Impact on the Company}

In order to examine the impact of the determinants of leverage on the company which influences in the selection of the source of financing investmentsOLS Simple Linear Regression analysis technique has been used to test the developed hypothesis

(1) $\mathrm{OL}_{\mathrm{i}, \mathrm{t}}=\alpha_{\mathrm{i}, \mathrm{t}} \beta_{1}\left(\mathrm{SZ}_{\mathrm{i}, \mathrm{t}}\right)+\beta_{2}\left(\mathrm{GR}_{\mathrm{i}, \mathrm{t}}\right)+\beta_{3}\left(\mathrm{CA}_{\mathrm{i}, \mathrm{t}}\right)+\beta_{4}\left(\mathrm{TL}_{\mathrm{i}, \mathrm{t}}\right)+€_{i, t}$

(2) $\mathrm{FL}_{\mathrm{i}, \mathrm{t}}=\alpha_{\mathrm{i}, \mathrm{t}} \beta_{1}\left(\mathrm{SZ}_{\mathrm{i}, \mathrm{t}}\right)+\beta_{2}\left(\mathrm{GR}_{\mathrm{i}, \mathrm{t}}\right)+\beta_{3}\left(\mathrm{CA}_{\mathrm{i}, \mathrm{t}}\right)+\beta_{4}\left(\mathrm{TL}_{\mathrm{i}, \mathrm{t}}\right)+€_{i, t}$

(3) $\mathrm{CL}_{\mathrm{i}, \mathrm{t}}=\alpha_{\mathrm{i}, \mathrm{t}}+\beta_{1}\left(\mathrm{SZ}_{\mathrm{i}, \mathrm{t}}\right)+\beta_{2}\left(\mathrm{GR}_{\mathrm{i}, \mathrm{t}}\right)+\beta_{3}\left(\mathrm{CA}_{\mathrm{i}, \mathrm{t}}\right)+\beta_{4}\left(\mathrm{TL}_{\mathrm{i}, \mathrm{t}}\right)+€_{i, t}$

Here, the leverage Ratios i.e. Operating Leverage (OL), Financial Leverage (FL) and Combined Leverage(CL) ratio of the company have been used as dependent variables and variables like growth rate (GR), Size (SZ), Liquidity (CA), Tangibility (TL) have been used as independent variables. $i$ identifies the company, $t$ expresses the time variable $(\mathrm{t}=2006$ to 2016); $\beta_{\mathrm{s}}$ are the parameters to be estimated, $\alpha$ represents the constant term and $€$ represents the error term of the model.

\subsection{Measure of Leverage Impact on the Performance}

In order to examine the of leverage on the financial performance of the company OLS Simple Linear Regression analysis technique has used to test the developed hypothesis as because the dependent and independent variable is numeric (scale) and under thissituation the prediction power of regression analysis is stronger as compared with the other technique.

(1) $\operatorname{ROA}_{i, t}=\alpha_{i, t}+\beta_{1}\left(\right.$ Size $\left._{i, t}\right)+\beta_{2}\left(\right.$ Growth $\left._{i, t}\right)+\beta_{3}\left(\right.$ Liquidity $\left._{i, t}\right)+$ $\beta_{4}\left(\right.$ Tangibility $\left._{\mathrm{i}, \mathrm{t}}\right)+\beta_{5}\left(\mathrm{OL}_{\mathrm{i}, \mathrm{t}}\right)+\beta_{6}\left(\mathrm{CL}_{\mathrm{i}, \mathrm{t}}\right)+\beta_{7}\left(\mathrm{FL}_{\mathrm{i}, \mathrm{t}}\right)+€_{i, t}$

(2) SHROA $_{i, t}=\alpha_{i, t}+\beta_{1}\left(\right.$ Size $\left._{i, t}\right)+\beta_{2}\left(\right.$ Growth $\left._{i, t}\right)+$ $\beta_{3}\left(\right.$ Liquidity $\left._{\mathrm{i}, \mathrm{t}}\right)+\beta_{4}\left(\right.$ Tangibility $\left._{\mathrm{i}, \mathrm{t}}\right)+\beta_{5}\left(\mathrm{OL}_{\mathrm{i}, \mathrm{t}}\right)+\beta_{6}\left(\mathrm{CL}_{\mathrm{i}, \mathrm{t}}\right)$ $+\beta_{7}\left(\mathrm{FL}_{\mathrm{i}, \mathrm{t}}\right)+€_{i, t}$

Here, the profitability and risk adjusted ratio are used as dependent variable i.e. ROA (Return in assets) and SHROA (Risk adjusted ROA) and the variables like Leverage Ratios i.e. Operating Leverage (OL), Financial Leverage (FL) and Combined Leverage(CL) ratios of the company, growth rate (GR), Size (SZ), Liquidity (CA), Tangibility (TL) have been used as independent variables. $i$ identifies the company, $t$ expresses the time variable $\left(\mathrm{t}=2006\right.$ to 2016); $\beta_{\mathrm{s}}$ are the parameters to be estimated, $\alpha$ represents the constant term and $\epsilon$ represents the error term of the Model.

\section{Results \& Discussion}

Table 1 represents the descriptive statistics of the company from 2007-2016. A very high degree of consistent growth has been reflected by the total assets of the company supported by its $\mathrm{CV}$ and CAGR values but it not as high as compared to currents assets of the firm which shows the annual growth of 9.66 per cent. On the contrary, the annual growth rate of fixed asset of the company was found very low i.e. only 4.92 per cent only. The average ROA of the company shows the value of 0.05 which has also increased notably at 11.61 per cent growth rate. The financial leverage ratio of the firm reflected an average value of 1.39 which replicate a negative growth followed by operating and combined leverage ratios of the company. As far as earnings are concerned the overall profitability of the firm is not very satisfactory it was found very inconsistent as reflected by its $\mathrm{CV}$ values but overall growth of the company in terms of earnings of profit was found quite satisfactory in nature i.e. 20.56 per cent. 
Table 1. Descriptive Statistics(2007-2016).

\begin{tabular}{lllllllllll}
\hline Statistics & TA(In Rs.) & ROA & SHROA & CA & CL & FA & FL & OL & CL & PAT \\
\hline$M E A N$ & 3186.14 & 0.05 & 1.79 & 884.84 & 1150.44 & 1140.23 & 1.39 & 8.69 & 11.26 & 181.87 \\
$S D$ & 943.52 & 0.03 & 1.00 & 348.84 & 643.01 & 213.47 & 0.54 & 4.59 & 8.27 & 138.61 \\
$C V$ & 29.61 & 55.96 & 55.96 & 39.42 & 55.89 & 18.72 & 38.80 & 52.77 & 73.40 & 76.21 \\
$M A X$ & 4962.57 & 0.09 & 3.05 & 1495.63 & 2257.41 & 1623.81 & 2.77 & 20.61 & 28.56 & 432.14 \\
$M I N$ & 2209.57 & 0.01 & 0.44 & 497.27 & 505.76 & 982.78 & 1.06 & 5.34 & 3.12 & 31.08 \\
CAGR(In \%) & 8.33 & 11.61 & 11.25 & 9.66 & 14.62 & 4.92 & -2.21 & -2.88 & -5.02 & 20.56 \\
\hline
\end{tabular}

Source: Authors Estimation based on secondary Data collected from the Annual Reports of the TVS Company from 2007-2016 (www.tvsmotor.com). Abbreviation:TA= Total Assets, ROA(Return on Assets), SHROA( Risk Adjusted ROA), CA(Current Assets), CL(Current Liabilities), FA(Fixed Assets), FL(Financial Leverage), OL(Operating Leverage), CL(Combined Leverage), PAT(Profit After Tax).

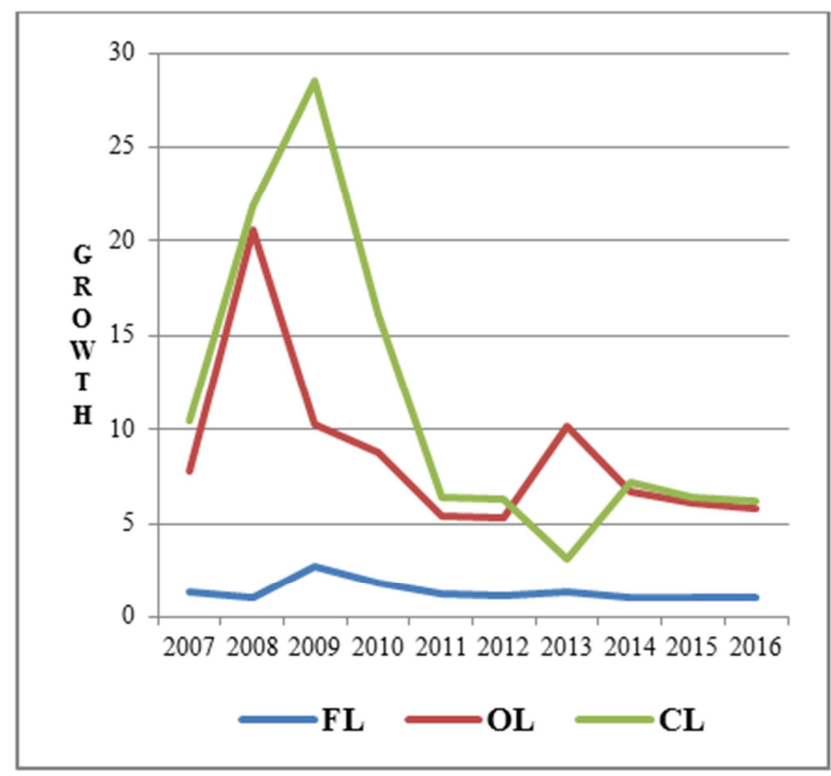

Figur 1. Trend in Leverage Ratios of the TVS Company (2007-2016).

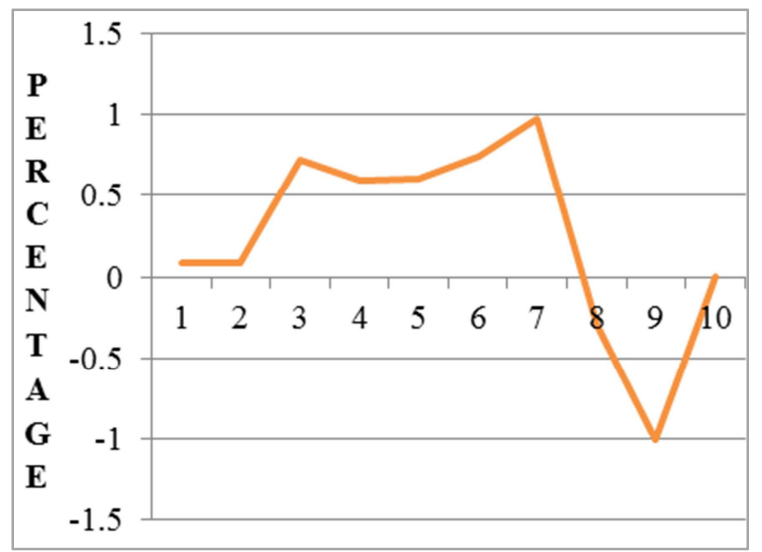

Figure 2. Correlation between Financial and Operating Leverage of the Company(2007-2016).

Figure 1 represents the trend in leverage ratios of the TVS Company from 2007 to 2016. A mixed trend of increase and decrease has been recorded in the financial leverage ratio trend line of the company in the initial years of study from 2007 to 2009 . After that stable trend line has been exhibited by the financial leverage ratio at the end of the study period. On the other hand, operating leverage ratio has displayed a volatile trend during the entire period of the study except the last few years in which it reflected a constant and stable trend. So, from the above trend line it can seen that operating leverage ratio has a more influence in determining the overall volatility of combined leverage ratio trend. The figure 2 represents the degree of correlation between operating and financial leverage of the company from 2007-2016. A very high degree of positive correlation exists between the leverage ratios of the company during the initial period of the study, which is an indication that the company is maintaining a rational proportion of the both in a parallel manner. This was not followed during the later period of the study in which negative correlation between both ratios has been observed.

\subsection{Test of Significance}

Table 2. Anova Leverage Ratios of the TVS company (2007-2016).

\begin{tabular}{|c|c|c|c|c|c|c|}
\hline \multicolumn{7}{|l|}{ Summary } \\
\hline Groups & \multicolumn{2}{|l|}{ Count } & Sum & \multicolumn{2}{|c|}{ Average } & Variance \\
\hline$F L$ & \multicolumn{2}{|l|}{10} & 13.88 & \multicolumn{2}{|c|}{1.38} & 0.28 \\
\hline$O L$ & \multicolumn{2}{|l|}{10} & 86.91 & \multicolumn{2}{|l|}{8.69} & 21.03 \\
\hline$C L$ & \multicolumn{2}{|l|}{10} & 112.63 & \multicolumn{2}{|c|}{11.26} & 68.34 \\
\hline \multicolumn{7}{|l|}{ Anova Table } \\
\hline Source of Variation & SS & Df & MS & $\mathrm{F}$ & $\mathrm{P}$-value & F crit \\
\hline Between Groups & 524.92 & 2 & 262.46 & 8.78 & 0.001 & 3.35 \\
\hline Within Groups & 806.98 & 27 & 29.88 & & & \\
\hline
\end{tabular}

Source: Authors Estimation Based on Secondary Data collected from the Annual Reports of the Company(www.tvsmotor.com) (2007-2016), Computed using SPSS 16.

Table 2 represents the test of significance results of the financial, operating and combined leverage ratio of the company during the period of 2007-2016. In order to know whether there exists any significant difference between different leverage ratios of the company, ANOVA test has been done. Where it has been found that the calculated value of $\mathrm{F}$ i.e. 8.78 is greater thanthe tabulated value i.e. 3.35, which is found statistically significant hence and it can be said that there exists some significant difference in the mean values of leverage ratios of the company.

\subsection{Measure of Leverage Impact on the Company}

In order to identify the manner in which leverage (financial, operating and combined) impacts on the overall performance of the company, it is first necessary to analyze the relationship between the dependent and explanatory variables. 
Table 3. Correlations between Dependent and Explanatory Variables.

\begin{tabular}{llllllll}
\hline & FL & OL & CL & SIZE & GR & CA & TL \\
\hline FL & 1 & .090 & $.744^{*}$ & -.406 & .044 & .509 & .308 \\
OL & .090 & 1 & .620 & -.568 & -.499 & .522 & $.723^{*}$ \\
CL & $.744^{*}$ & .620 & 1 & -.596 & -.106 & $.673^{*}$ & $.709^{*}$ \\
SIZE & -.406 & -.568 & -.596 & 1 & .563 & $-.929^{* *}$ & $-.846^{* *}$ \\
GR & .044 & -.499 & -.106 & .563 & 1 & -.496 & -.494 \\
CA & .509 & .522 & $.673^{*}$ & $-.929^{* *}$ & -.496 & 1 & $.862^{* *}$ \\
TL & .308 & $.723^{*}$ & $.709^{*}$ & $-.846^{* *}$ & -.494 & $.862^{* *}$ & 1 \\
\hline
\end{tabular}

*Correlation is significant at the 0.05 level (2-tailed)\& ** Correlation is significant at the 0.01 level (2-tailed).

Source: Authors estimation based on secondary data, computed using SPSS 16.

Abbreviation: $\mathrm{FL}=$ Financial Leverage, $\mathrm{OL}=$ Operating Leverage, $\mathrm{CL}=$ Combined leverage, SIZE $=$ Total Assets of thecompany, GR $=$ Growth in Total Assets, $\mathrm{CA}=$ Current Assets Ratio, $\mathrm{TL}=$ Tangibility Ratio.

Table 3 represents the correlation analysis between dependent and explanatory variables of the used in the study. There exists negative correlation between financial leverage and size of the firms which indicates that with increase in the financial risk of the company the total assets of the firm reduces. Operating leverage also bears a negative correlation with the size and growth rate of the company but having a positive relation with the tangibility ration of the company and found significant at 0.05 level of significance. So it indicates the overall proportion of the company's fixed assets has also increased with the increase in the operating leverage ratio of the company. Combined leverage bears negative correlation with growth rate and size of the company but it swallows positive relation with the current assets and tangibility ratios of the company and it was found significant also at 0.05 level of significance. Size bears negative correlation with CA and TL ratios of the firm, it indicates that with the increase in the overall assets of the firm the liquidity position of the firm reduces and proportion of fixed assets in the total assets also decreases. Current assets ratio and tangibility ratios of the firm bears very high degree of positive correlation and it was also found significant at 0.01 level of significance.

\subsection{Regression Results of Leverage Impact on the Company}

Table 4 represents the regression results between dependent (OL, FL, CL) and independent variables (SZ, CA, GR, TL). The explanatory variable have been found insignificant in the test results so it can be concluded that, the leverage determinants has no significantimpact on operating, financial and combined leverage of the company and it does not play any role in making investment decisions. Hence our first null hypothesis $\left(\mathrm{H}_{01}\right)$ i.e. the leverage determinants have no significant impact on the financial, operating and combined leverage of the company has been accepted.

Table 4. Regression Results.

\begin{tabular}{|c|c|c|c|c|c|c|}
\hline \multirow[t]{2}{*}{ Regressors } & \multicolumn{2}{|c|}{ Operating leverage (OL) } & \multicolumn{2}{|c|}{ Financial Leverage (FL) } & \multicolumn{2}{|c|}{ Combined Leverage(CL) } \\
\hline & Coef.(Std. Err.) & Sig & Coef.(Std. Err.) & Sig & Coef.(Std. Err.) & Sig \\
\hline Firm Size(SZ) & $-.198(.003)$ & .782 & $.003(.000)$ & .997 & $.035(.005)$ & .954 \\
\hline Firm Liquidity(CA) & $-.584(25.543)$ & .502 & $1.091(3.369)$ & .284 & $.429(39.199)$ & .560 \\
\hline Growth Rate(GR) & $-.064(.192)$ & .870 & $.462(.025)$ & .322 & $.514(.295)$ & .167 \\
\hline Tangibility(TL) & $1.035(47.571)$ & .137 & $-.365(6.275)$ & .603 & $.661(72.990)$ & .242 \\
\hline Cons(Constant term) & 27.285 & .900 & 3.599 & .800 & 41.864 & .285 \\
\hline$\overline{\mathrm{R}}^{2}$ & .576 & & .464 & & .693 & \\
\hline Observations (Adj R²) & .236 & & .036 & & .447 & \\
\hline
\end{tabular}

Source: Authors estimation based on secondary data, computed using SPSS 16.

\subsection{Regression Results of Leverage Impact on the Performance of the Company}

Table 5 represents the regression results between dependent and independent variables. The independent variables have been found insignificant i.e. above.005. So, we cannot say whether ROA and SHROA is making positive or negative impact on the overall performance of the company as it was found insignificant in the above table. So our null hypotheses i.e. $\mathrm{H}_{02} \& \mathrm{H}_{\mathrm{O} 3}$ have been accepted and it can be said that the financial, operating and combined leverage of the company has no significant impact on ROA (Return on Assets) and Risk Adjusted (SHROA) of the company.

Table 5. Regression Results.

\begin{tabular}{|c|c|c|c|c|}
\hline \multirow{2}{*}{ Regressors } & \multicolumn{2}{|c|}{ Return on Assets(ROA) } & \multicolumn{2}{|c|}{ Risk AdjustedReturn on Assets(SHROA) } \\
\hline & Coef.(Std. Err.) & Sig & Coef.(Std. Err.) & Sig \\
\hline Firm Size(SZ) & $.076(.000)$ & .789 & $.320(.002)$ & .604 \\
\hline Firm Liquidity(CA) & $-.370(.072)$ & .393 & $-.207(18.838)$ & .801 \\
\hline Operating Leverage(OL) & $.805(.002)$ & .076 & $-.456(.410)$ & .454 \\
\hline Financial Leverage(FL) & $-.755(.016)$ & .122 & $.700(4.317)$ & .371 \\
\hline Combined Leverage(CL) & $.721(.002)$ & .236 & $.673(.416)$ & .535 \\
\hline Tangibility(TL) & $-.251(.182)$ & .534 & $-.164(47.783)$ & .838 \\
\hline Cons(Constant term) & .090 & .116 & 23.628 & .596 \\
\hline$\overline{\mathrm{R}}^{2}$ & .978 & & .903 & \\
\hline Observations(Adj R²) & .901 & & .565 & \\
\hline
\end{tabular}

Source: Authors estimation based on secondary data, computed using SPSS 16. 


\section{Conclusion}

The primary objective of the study to find out the impact of leverage determinants of the company which influence in the selection of the source of financing investments and to measure the impact of leverage on the performance of the company. For analysis purpose the basic statistical tools like Mean, SD, CV, CAGR, ANOVA(one way) have been used and in order to measure the impact an OLS simple Linear regression model has been used. The study covers a period of ten years from 2006 to 2016. A mixed trend of increase and decrease has been recorded in the financial leverage ratio trend line of the company in the initial years of study from 2007 to 2009 and it was found that operating leverage ratio has a more influence in determining the overall volatility of combined leverage ratio trend. During the later period of the study in which negative correlation between operating and financial leverage ratios have been observed. Based on the statistical test(ANOVA) it was also found that there exists some significant difference in the mean values of leverage ratios of the company. The regression results suggested that the operating, financial and combined leverage of the company does not play any major role in making investment decisions of the company. And it was also found that the financial, operating and combined leverage of the company has no significant impact on ROA (Return on Assets) and Risk Adjusted (SHROA) of the company.

\section{References}

[1] Alkhatib, K. (2012). The Determinants of Leverage of Listed Companies. International Journal of Business and Social Science, 3(24), 65-73.
[2] Baggs, J., \& James, A. (2005). Trade Liberalization, Profitability and Financial Leverage. Analytical Studies Branch Research Paper Series, 24(2), 3rd ser., 283-287.

[3] Fengju, X., Fard, Y. R., Mehar, G. L., \&Akhteghan, N. (2013). The Relationship Between Financial Leverage and Profitability with an emphasis on Income Smoothing in Iran's Capital Market. European Online Journal of Natural and Social Sciences, 2(3), s, 154-164.

[4] Gupta, S. K., \& Sharma, R. K. (2011). Financial Management. Delhi: Kalyani Publisher.

[5] Javed, H. Z., Rao, H., Akram, B., \&Nazir, F. M. (2015). Effect of Financial Leverage on Performance of the Firm: Empirical Evidence from Pakistan. SPOUDAI Journal of Economics and Business, 64(1), 2nd ser., 87-95.

[6] Khan, M. K., \& Jain, P. K. (2010). Financial Management. Delhi, Delhi: TataMegraw - Hill Publishing Company Ltd.

[7] Khedkar, B. E. (2015). A Study of Leverage Analysis and Profitability for Dr Reddy's Laboratories. International Journal of Research in Engineering and Social Sciences, 5(5), 93-97.

[8] Maheswari, S. N. (2009). Management Accounting and FinancialControl. Delhi: Sultan Chand \& Sons

[9] Ojo, S. K. (2012). The Effect of Financial Leverage on Corporate Performance of Some Selected Companies in Nigeria. Canadian Social Science, 8(1), 85-91.

[10] Reddy, T. S., Parasad, H., \& Reddy, Y. (2010). ManagementAccounting. Chennai: Margam Publications. 